czących autorów powodują, że publikacja winna zostać zauważona i brana pod uwagę w dalszej dyskusji nad istotą pedagogiki religii i konsekwentnie wychowania religijnego.

Zbigniew Marek*

\title{
Jarosław Michalski, Sens życia a pedagogika. Impulsy myśli Viktora E. Frankla, Wydawnictwo Naukowe UMK, Toruń 2011, ss. 300.
}

Lektura prac ks. dr. hab. Jarosława Michalskiego, prof. UMK, przekonuje, że niemal od początku naukowej drogi przejawiał on wrażliwość na taki sposób opisywania człowieka, który ukazuje go jako poszukującego prawdy i sensu sprzyjających życiu. Temu nachyleniu refleksji nad wychowaniem człowieka ks. J. Michalski dał wyraz między innymi w pracy habilitacyjnej Edukacja i religia jako źródła rozwoju egzystencjalno-kognitywnego. Studium hermeneutyczno krytyczne (2004). Zdaniem J. Michalskiego, studia nad człowiekiem nie znajdują uzasadnienia, jeśli nie dotyczą ujęcia całościowego, wspierającego sens życia (zob. s. 14). W powyższej pracy podkreślał „ciągłą niezbędność tworzenia sensu” (tamże, s. 15).

Do pytania o sens powrócił w najnowszej publikacji Sens życia a pedagogika. Impulsy myśli Viktora E. Frankla (2011). Uczynił to w sposób bardziej zasadniczy niż w pracy poprzedniej, gdzie zagadnienie sensu było motywem mniej istotnym dla podejmowanego tam pytania badawczego.

W książce, która jest przedmiotem niniejszej recenzji, ks. J. Michalski podejmuje próbę zwrócenia uwagi na istotność powiązań pedagogiki z pytaniem o sens, który autor ujmuje jako doświadczenie egzystencjalne, a nie jako czynność intelektualną. Polem jego szczególnego zainteresowania badawczego stała się egzystencjalna koncepcja człowieka V. E. Frankla, stojąca w opozycji do biologistycznego, redukcjonistycznego i reifikującego traktowania człowieka podczas jego egzystencji.

Recenzowana praca składa się z wprowadzenia, dwu części, zakończenia, bibliografii oraz obcojęzycznego streszczenia. Została wydana przez Wydawnictwo Naukowe Uniwersytetu Mikołaja Kopernika w Toruniu. Liczy 300 stronic. Recenzje wydawnicze napisali: prof. dr hab. Józef Binnebesel i ks. prof. dr hab. Mirosław Kalinowski.

* Ks. prof. dr hab. Zbigniew Marek SJ - profesor zwyczajny w Instytucie Nauk o Wychowaniu Akademii Ignatianum w Krakowie. 
We wprowadzeniu autor nakreśla w sposób zwarty tło podejmowanej problematyki i już na początku formułuje główną tezę wyznaczającą perspektywy analiz niniejszej pracy. Brzmi ona: pytanie o sens ma duże znaczenie dla pedagogiki. Teza ta uzasadnia sposób wyjaśniania i argumentowania zawartego w pracy kluczowego problemu badawczego, którym jest pytanie o sens oraz jego związki z teorią i praktyką pedagogiczną (zob. s. 10). Odpowiedzi na powyższe pytanie badawcze szuka autor, analizując prace zwarte i artykuły V. E. Frankla. Zdaniem J. Michalskiego, pytanie o wartości pedagogiczno-wychowawcze, postawione na podstawie prac z zakresu logoterapii, jest istotne dla analizy poglądów Frankla i dla współczesnej teorii i praktyki pedagogicznej (zob. s. 17).

Ks. J. Michalski podkreśla we wprowadzeniu, że „,wspólną płaszczyzną analizy egzystencjalnej, zaproponowanej przez Frankla, jak i pedagogiki filozoficzno-transcendentalnej jest traktowanie człowieka w jego pełnym osobowym i integralnym wymiarze" (s. 11). Punktem fundamentalnym tej koncepcji jest noetyczny, duchowy wymiar człowieka, akcentujący jego płaszczyznę osobową (nie tylko społeczną) w relacji z Innym.

Ten sposób traktowania człowieka wykazuje oryginalność ujęcia Frankla oraz podkreśla odrębność jego analizy egzystencjalnej w stosunku do psychoanalizy oraz psychologii eksperymentalnej, które to kierunki zawężały całościowy obraz człowieka, abstrahowały od jego duchowości, wartościowania, a przede wszystkim odnosiły się głównie do stanów podświadomości. Franklowi chodziło o stworzenie alternatywy zarówno w stosunku do psychoanalizy Freuda, jak również psychologii indywidualnej Adlera (zob. s. 80). Logoterapia dokonuje przezwyciężenia subiektywnej pustki w zakresie braku sensu poprzez to, że stara się pomóc osobom cierpiącym na frustrację egzystencjalną przy poszukiwaniu sensu w życiu. Frankl podkreślał ważność oparcia wartościowania na wartościach religijnych, stałych, niezmiennych i obiektywnych. Od nich uzależniał odnajdywanie prawdziwego sensu i celu życia (zob. s. 13).

Autor prezentuje nadto we wprowadzeniu przyjętą w niniejszej pracy metodę badawczą: monografii, i jako uzupełniającą - metodę biografii tematycznej. Widać więc, że wprowadzenie jest dobrze przemyślanym i zgodnym z wymogami metodologicznymi zaproszeniem czytelnika do wejścia w lekturę pracy.

Jak to już wyżej wskazałem, praca składa się z dwóch części. W pierwszej zatytułowanej: Człowiek i jego egzystencjalne problemy. Poszukiwanie odpowiedzi w propozycji V. E. Frankla mamy zarysowane teoretyczne tło dla założeń teorii i metody Frankla, wynikających z analizy sytuacji egzystencjalnej człowieka i charakterystyki kategorii sensu. Mamy tu przedstawiony teoretyczny obraz logoterapii, ukazujący czytelnikowi fundamentalne 
kwestie związane z biologistycznym i redukcjonistycznym traktowaniem człowieka, będących owocem psychologii indywidualnej A. Adlera i psychoanalizy Z. Freuda.

Dla czytelnika bardzo ważny i przykuwający uwagę jest rozdział I, w którym ks. J. Michalski przedstawia drogi życia V. E. Frankla oraz jego teorię. Jak to podkreśla nasz autor - „nie można zrozumieć metody i myśli psychoterapeutycznej Frankla w oderwaniu od jego biografii osobistej” (s. 23). Biografia ta naznaczona była najpierw bardzo wczesnymi studiami nad filozofią Artura Schopenahauera, spotkaniem z Zygmuntem Freudem, wykształceniem medycznym, specjalizacją $\mathrm{w}$ dziedzinie neurologii i psychiatrii. Jak to mamy ukazane w tym rozdziale, od początku medycznej drogi Frankl był wyczulony na dogłębną analizę stanu egzystencjalnego pacjenta traktowanego osobowo, a jego refleksja naukowa od początku bazowała na wartościach i stopniowo dopracowywana stała się teoretyczną podstawą jego teorii logoterapii. Rozumiał on ją jako poszukiwanie w terapii ,logosu życia, sensu życia, integrujących skuteczność terapii” (s. 29). Ukazując problem analizy egzystencjalnej, przeciwstawił ją tradycyjnej psychoanalizie. Jak to wskazuje ks. J. Michalski, na tym wczesnym etapie życia Frankl był pod wpływem pism filozoficznych Maksa Schelera, Karla Jaspersa i Martina Heideggera (zob. s. 30).

W biografii osobistej Frankla ważnym przeżyciem była II wojna światowa i pobyt (w latach 1942-1945) aż w czterech hitlerowskich obozach koncentracyjnych. Stracił on w tym czasie wszystkich swoich bliskich, a więc rodziców i żonę. „Osobowe doświadczenia Frankla, a także innych współwięźniów potwierdziły tylko jego intuicję co do wiary w głębię ludzkiego wnętrza i autotranscendencję człowieka. Sam Frankl jest dowodem na to, iż człowiek jest w stanie przeżyć najtragiczniejsze chwile swojego życia pod warunkiem świadomości istnienia wartości, orientacji na te wartości" (s. 31-32). Powyższy cytat z pracy ukazuje, jak ważne były to przeżycia i doświadczenia nie tylko dla osobistej drogi życia Frankla, ale - co tu jest najważniejsze - dla jego myślenia o człowieku, sensie życia i sensie śmierci. Ks. J. Michalski cytuje w swej pracy ważkie słowa Frankla: „Człowiek był zdolny wybudować krematoria, w których palił ludzi, ale w tym samym czasie człowiek był zdolny wchodzić do tych krematoriów z podniesioną głową, recytując żydowską modlitwę o śmierć Schema Izrael lub modląc się słowami Ojcze nasz" (s. 35).

Tak więc dla Frankla istotna była świadomość i osobiste przekonanie każdego o sensie własnego życia. Powyższe doświadczenia i przekonania o sensie życia były ciągle inspiracją do bardzo oryginalnych poszukiwań naukowych. Jest twórcą teorii logoterapii, zaproponował analizę egzystencjalną, w której szczególne miejsce zajmowała kategoria odpowiedzialno- 
ści. Podkreślał znaczenie duchowości jako wymiaru specyficznie ludzkiego: „To, co w człowieku duchowe, stanowi o istocie człowieka, tylko urzeczywistniając swoją duchową naturę, człowiek prowadzi autentyczną egzystencję" (s. 51).

W II rozdziale: Utrata i kryzys sensu. Perspektywa fenomenologiczna ks. J. Michalski wskazuje na zjawisko pustki egzystencjalnej współczesnego człowieka, szczególnie młodego, jako przejaw zagubienia i kryzysu. Zjawisko pustki egzystencjalnej i frustracji Frankl opisywał w licznych pracach. Ks. J. Michalski przedstawia istotne elementy tego zjawiska w ujęciu Frankla, omawia podstawowe postawy człowieka jako wynik utraty poczucia sensu, analizuje przyczyny. Należy podkreślić, że rozdział ten, zgodnie z podstawowym pytaniem badawczym, postawionym przez autora, zawsze nawiązuje do próby pedagogicznego odczytania poglądów Frankla. Przedstawia je w kontekście poglądów współczesnych autorów zajmujących się wychowaniem w społeczeństwie pluralistyczno-demokratycznym (np. M. Heitger, I. Breinbauer, P. Amann, Z. Kwieciński, K. Popielski).

Drogą wyjścia z kryzysu i frustracji jest odnalezienie sensu życia (zob. rozdział III: Sens jako droga wyjścia z kryzysu). Zdaniem Frankla wyjście z kryzysu, odnalezienie sensu i drogi do niego wymagają sprawnego funkcjonowania wszystkich wymiarów ludzkiego życia: cielesnego, psychicznego i duchowego. Według Frankla właśnie wymiar duchowy dotyka najgłębszego rdzenia człowieka, jednostki. „To «osoba w nas» jest tym, co czyni człowieka prawdziwie ludzkim i odróżnia go od zwierząt" (s. 94). Warto w tym rozdziale niniejszej pracy zwrócić uwagę na podrozdział zatytułowany Pojęcie sensu i wartości (s. 97 n.).

Frankl, jak to podaje ks. J. Michalski, stwierdza, że „sensem życia człowieka jest stawanie się tym, kim może on się stać i kim ma się stać”. Frankl ukazuje człowieka otwartego na wartości, na urzeczywistnianie tych wartości (zob. s. 97). Czytelnik otrzymuje w tym miejscu pracy uporządkowany obraz wartości, ich rodzajów. Ciekawy jest fragment o wartościach postawy związanych ze stosunkiem do przeznaczenia i cierpienia, czyli wartościach postawy związanych z cierpieniem i znoszeniem swojego losu. Cierpienie w tym ujęciu staje się źródłem tożsamości i wartości człowieka. Jak wyjaśnia ks. Michalski, pojęcie „sens” jest komplementarne w stosunku do pojęcia „wartość” i ma zawsze odniesienie do wartości: „zajęcie postawy wobec wartości, urzeczywistnianie wartości prowadzi do wypełnienia ludzkiego bytu sensem" (s. 101). Ks. Michalski kilka razy w tej pracy podkreśla, że człowiek jest jedyną istotą na ziemi, która stawia pytania o sens. I dodaje, że nie tyle człowiek stawia pytania dotyczące sensu, ale te pytania są mu stawiane przez życie i on musi na te pytania odpowiedzieć (zob. s. 101-102). Ważne jest podkreślenie, że problem sensu dotyczy nie tylko życia jako cało- 
ści, ale każdej poszczególnej sytuacji życiowej. W odnalezieniu sensu ukrytego w każdej sytuacji życia pomaga człowiekowi sumienie.

Frankl podkreślał, że dążenie do sensu jest podstawowym wyrazem duchowości człowieka. „Jego realizacja sprawia, że osoba ludzka może się w pełni rozwinąć. Natomiast brak tej realizacji powoduje frustrację egzystencjalną i może prowadzić do nerwicy noogennej (s. 103).

W ostatnim rozdziale części I: Pytanie o sens a osoba pytająca, pytanie o sens jest postawione w kontekście nauczania i wychowania. Bez pytań nie jest możliwy żaden rodzaj kształcenia. Pytanie, analogicznie do roli, jaką pełni w nauczaniu, jest znaczącym elementem znalezienia sensu życia. Jest to pytanie, które - jak to już w tej pracy zaznaczono - pojawia się ciągle na nowo. Jest ono istotne i ważne dla pedagogów w procesie nauczania i uczenia się (zob. s. 115-116). Bardzo ważną rolę odgrywa w możliwości odnalezienia sensu zasada dialogu w relacji międzyludzkiej. W logoterapii zatem stosuje się zasady oddziaływań pedagogicznych, a i w działaniu pedagogicznym można realizować formy pracy z pacjentem właściwe dla logoterapii. Ks. J. Michalski ciekawie ukazuje dialog i relacyjność w logoterapii (zob. s. 122-123). Zawsze jednak nośnikiem sensu będzie osoba jako podmiot.

Druga część pracy: Znaczenie pytania o sens życia dla pedagogiki, jest poświęcona pedagogicznemu wymiarowi logoterapii Frankla i ukazaniu znaczenia pytania o sens dla oddziaływań wychowawczych. W początkowej partii tego rozdziału ks. J. Michalski ukazuje podstawy i zasady myślenia i działania pedagogicznego. Wskazując na filozoficzne podstawy pedagogiki, autor podkreśla, że pedagogika teoretyczna nie może zrezygnować z pytań filozoficznych. Jeżeli rezygnuje ona z pytań o znalezienie sensu, „to sama sprowadza się do nauki instrumentalnej, do technologicznego modelu, łatwego do praktycznego wykorzystania" (s. 145). Jeżeli pedagogika utraci, ze względu na swe idee przewodnie, pytający charakter filozoficzny, ugruntowujący jej fundamenty, to wówczas doprowadzi siebie do absurdu, pozbawiając się podłoża, istotnego nie tylko z teoretycznego, ale i praktycznego punktu widzenia - podkreśla ks. J. Michalski. Ukazuje on następnie wzajemne relacje między pedagogiką a psychoterapią, różnice i punkty styczne.

$\mathrm{W}$ rozdziale II tej części pracy autor podejmuje zagadnienie pytania w ludzkiej egzystencji. Autor przypomina podejmowane już wyżej związki pytania o sens z pytaniem o wartość i znaczenie tego związku w kształceniu człowieka (zob. s. 173-174). Nie da się „oddzielić pytania o sens od pytania o wartości absolutne, o esencję, veritas maxima, od Logosu lub pytania o Boga. Kto pyta o sens życia, pyta zarazem o swój udział w wartościach absolutnych, sięga w tym pytaniu do transcendencji oraz przechodzi z wymiaru czasowego do ponadczasowego" - podkreśla ks. J. Michalski. 
Pytanie o transcendencję wcale nie przekreśla, ale wręcz zakłada pytanie o relację do „ty”. Tym, co porządkuje szukanie odpowiedzi na pytania o sens w różnych sytuacjach i relacjach, jest sumienie. Ważne z pedagogicznego punktu widzenia jest przypomnienie, które autor tej pracy formułuje następująco: „Nie istnieje kształcenie bez wychowania do sumienia. Wynika stąd, że można wprawdzie odmówić człowiekowi wykształcenia, nigdy nie można natomiast odmówić mu postępowania zgodnego z własnym sumieniem" (s. 182).

Jak podkreśla ks. J. Michalski, „konieczność kształcenia się, jak i konieczność pytania o sens stanowią specyfikę ludzkiej egzystencji i są zadane człowiekowi w dziele, którym jest on sam" (s. 189).

Powyższą myśl autor rozwija w następnym rozdziale, zatytułowanym: Pytanie o sens. Przeprowadza on tu analizę takich pojęć, jak: pytanie o sens, utrata sensu, pytanie o wartość, sumienie i odpowiedzialność. Zagadnienia te, już uprzednio obecne w tej pracy, tu podawane są w kontekście pedagogicznym. Autor pogłębia rozważania na temat analizy egzystencjalnej, którą Frankl zajmował się od początku swej naukowej drogi. Celem Frankla było przezwyciężenie psychologizmu w obrębie psychoterapii. Był on przeciwny wszelkim próbom redukcjonizmu, pozbawiającego człowieka wymiaru ludzkiego, zwłaszcza wymiaru duchowego w obrazie człowieka. Dlatego też Frankl podkreślał, że człowiek jest istotą znajdującą się ustawicznie na drodze poszukiwania sensu. Logoterapia, którą stworzył, jest zorientowana na sens.

Pracę zamyka rozdział, zatytułowany: Osoba pytająca. W postrzeganiu osoby Frankl dystansuje się od zawężonej wizji człowieka, typowej dla wizji przyrodniczej. Podkreśla on, że człowiek znajduje się na drodze poszukiwania sensu własnego życia. Nie zamyka się on w tym szukaniu na samym sobie, ale otwiera się ku innym bytom, także ku transcendencji. Typowe dla Frankla jest cytowane w tej pracy stwierdzenie: „człowiek jako całość jest człowiekiem tylko tam, gdzie całkowicie angażuje się w jakiejś sprawie, poświęca innej osobie. I całkiem staje się sobą, tam, gdzie traci z oczu samego siebie i zapomina o sobie" (s. 251). Stwierdzenie powyższe jest w swej istocie streszczeniem chrześcijańskiego pojęcia proegzystencji, istnienia „dla”.

Jak podkreśla ks. J. Michalski - podsumowując swoje wczytywanie się w teorię logoterapii Frankla - podjęcie próby pedagogicznego odczytania Frankla jest potrzebne i konieczne w odpowiedzi na pytania o to, jak zagadnienie kształtowania sensu ożywić w życiu społecznym, w edukacji, w edukacji religijnej, w myśleniu pedagogicznym, jak pomóc ludziom wchodzić na drogę, która nie prowadzi do nicości, lecz ku pełni bytu i życia.

Praca ks. J. Michalskiego - jako ciekawe i pionierskie odczytanie teorii Frankla - jest wybitnym w swej wartości studium penetrującym ważkie 
tereny z zakresu teorii i filozofii wychowania człowieka. Jest ona jednocześnie syntezą antropologiczno-egzystencjalnej i personalistycznej koncepcji człowieka jako osoby. Praca ta, podejmująca interesujący problem sensu życia, nie jest rejestrem gotowych odpowiedzi na sformułowane nieco wyżej pytania, ale jest ważnym zaproszeniem do odczytania problemu „sensu" i „sensu życia” jako istotnego przedmiotu rozstrzygnięć teoretyczno-pedagogicznych oraz do uznania „pytania o sens” jako jednego z kluczowych obszarów praktyki oddziaływań wychowawczych (zob. s. 260). Jest ona jednocześnie zaproszeniem do odczytania myśli Frankla także w wymiarze bardzo osobistego życia każdego czytelnika, który z tą myślą może - dzięki tej pracy - zetknąć się w sposób bardzo pogłębiony. Pracy tej nie uda się przeczytać jedynie z zobiektywizowanym dystansem, choć z punktu widzenia naukowego jest to poniekąd konieczne. Dotyka ona bowiem w czytelniku bardzo wrażliwej struny osobistego pytania o sens życia, cierpienia i ostatecznej odpowiedzi, której nie sposób zamknąć z perspektywy mędrca „szkiełka i oka”.

Wartości pracy ks. J. Michalskiego Sens życia a pedagogika. Impulsy myśli V. E. Frankla nie da się ograniczyć jedynie do kręgu refleksji pedagogicznej. Jesteśmy świadkami zjawiska wykluczania problematyki sensu nie tylko z obszaru dociekań pedagogicznych, ale też z obszaru współczesności pojętej o wiele szerzej niż tylko w aspekcie wychowawczym, zwłaszcza w promowanej wizji życia, gdzie „mieć” zdaje się dominować nad „być”. Zachwianie równowagi między „mieć” i „być” jest dziś źródłem utraty sensu życia oraz zaniku wrażliwości moralnej oraz wrażliwości na wartości wyższe, a zwłaszcza w pokoleniu ludzi młodych - jest źródłem poważnych i niszczących uzależnień.

Recenzowana praca ks. dra hab., prof. UMK, J. Michalskiego jest wartościowym studium, którym zapewne zainteresują się nie tylko pedagodzy czy filozofowie, ale i wielu innych odbiorców, stawia ona bowiem pytania, które bliskie są każdemu myślącemu człowiekowi, każdemu poszukującemu sensu życia. Zawiera ona ogrom treści ważnych dla współczesnego człowieka, niejednokrotnie zagubionego pośród meandrów życia i rozpaczliwie poszukującego sensu egzystencji.

Jerzy Bagrowicz *

* Ks. prof. zw. dr hab. Jerzy Bagrowicz jest kierownikiem Zakładu Katechetyki i Pedagogiki Religii na Wydziale Teologicznym Uniwersytetu Mikołaja Kopernika w Toruniu. 